\title{
Ecology of Thryonomys swinderianus In Ogoni Land
}

\author{
Opuogulaya, R (Corresponding author) \\ Department of Science Laboratory Technology, School of Applied Sciences, \\ Kenule Beeson Saro-Wiwa Polytechnic, P.M.B 20 Nigeria. \\ E-mail: ropuogulaya@gmail.com \\ Ekiyor, H. T \\ Department of Science Laboratory Technology, School of Applied Sciences, \\ Kenule Beeson Saro-Wiwa Polytechnic, P.M.B 20 Nigeria. \\ Aisuene, $\mathrm{F}$ \\ Department of Science Laboratory Technology, School of Applied Sciences, \\ Kenule Beeson Saro-Wiwa Polytechnic, P.M.B 20 Nigeria.
}

\begin{abstract}
The knowledge of the existence of Thryonomys swinderianus in Ogoni Land is not entirely exclusive, but not much is known of its ecology. The feeding and population ecology of Thryonomys swinderianus in Ogoni land was investigated in this research. The feed type, length of feeding bout and feeding rate was the scope of the feeding ecology. Annual hunt data was used to estimate its population; the annum being July 2017 to June 2018. Feed presented in captivity and inference from crops raided on in farms was the source of feed type. For feeding rate and length of feeding bout, direct observation in captivity was the method used. Thryonomys swinderianus is an herbivore feeding on plant species like elephant grass, cane sugar, pawpaw, banana, guava, African native pear, cassava (stem \& tuber), plantain, maize, yam, cocoyam, potato, watermelon, three leaf yam, soursop, melon, pumpkin and non-plant feed like fowl feed (finishers) and bread. The volume of feed Thryonomys swinderianus consume within 30 minutes is $103.5+/-11.4$ grams, feeds twice a day in captivity spending $97+/-6$ minutes to eat to full. It is a selective feeder in the wild both of plant species and part eaten, having a higher feed type range in captivity than in the wild. Its population before harvest commenced in July 2017 was six thousand and twenty. Its feeding activities on cultivated crops causes sever economic damage to farmers and set a conflict between itself and humans.
\end{abstract}

Keywords: Thryonomys swinderianus, population abundance; length of feeding bout; feeding rate; feed type.

DOI: $10.7176 / \mathrm{JSTR} / 5-4-10$

\subsection{INTRODUCTION}

Ernst Haeckel was first to coin and use the word "ecology" but it was Theophrastus that first described the interrelationship between organisms and their nonliving environment (Raven and Johnson, 1998; Stuart and Robert, 2012). Ecology has been defined variously: most definitions center around interactions between organisms, interactions between organisms and their environment, species abundance and distribution, transformation and flux of energy. Living organisms in the ecosystem interact with one another mainly through food relationships; competition, parasitism, predation, mutualism and commensalism (Ramalingam, 2012).

Thryonomys swinderianus is a herbivore with a wide range of nutritional intake (Fritzinger, 1995; Opara, 2010; Adeniye, 2014). The major component of its diet appear to be grasses that have high crude fiber content (Opara, 2010). According to Fritzinger 1995, grasses and cane are the natural diet while the National Research Council, NRC,1991 had reported earlier that elephant grass and sweet potatoes are the favorite feed of greater cane rats. 
Thryonomys swinderianus are endeared to gramineous plants that have succulent stalks like sugar cane, guinea grass, gamba grass, congo grass and do well with potatoes eat nuts, barks of anacardum, fruits such as mango, pawpaw, pineapple preferring plant parts that have lots of moisture and soluble carbohydrates (Fritzinger, 1995; Gochis, 2002; Agriculture Nigeria, 2014, Adeniye, 2014). They also feed on cultivated crops like groundnut, rice, maize, cassava, sweet potatoes, unripe plantain and also delight on the root and pitch of coconut and oil palm (Agriculture Nigeria, 2014; Adeniye, 2014). Thryonomys swinderianus is selective: it goes for succulent and more nutritious portion of grasses, thus wasting a lot of food around were it feeds, a sign hunters use to trace them (Ntiamoa-Baidu, 1997). In captivity, sugar cane, cassava peelings and corn stalk are some feed given to Thryonomys swinderianus with Pennisetum purpurem and Panicium maximum being the main forages given to them by most farmers on daily basis with the addition of kitchen leftovers by some farmers (Ntiamoa-Baidu, 1997; Adu et. al., 1999; Opara, 2010). Diet active pattern, availability of supplements and availability of labor affect feeding regime and since Thryonomys swinderianus eat more in the mornings and evenings with little in the afternoons; grasses should be administered in the mornings and evenings while supplements if available in the afternoon (Schrage and Yewande, 1999; Adu et. al., 2017). Opara 2010, has reported that the nutritional status of Thryonomys swinderianus is improved through provision of pelleted concentrate for supplementary feeding.

Thryonomys swinderianus is found only in Africa, from South of the Sahara and ranges from Gambia to South Sudan and from South to North Namibia and South Africa (Gochis, 2002; Opara, 2010). It is found in grasslands and wooded Savanna throughout the humid and sub-humid areas South of Sahara (NRC, 1991). It is typically found in association with reedbeds or in areas with dense, tall grasses with thick reed or cane-like stems typical of riverine and other similar habitats but can also be found anywhere dense grasses occur, particularly in damp or wet places with reedy grass (Opara, 2010; Child, 2016). Agricultural crops have greatly improved and expanded the ecological habitat for $T$. swinderianus from the Savannah region into cropped areas and secondary forest (Opara, 2010; Child, 2016). The distribution of Thryonomys swinderianus is determined basically by the availability of adequate grass species for food but are seldom found far from water and do not inhabit the rainforest, dry scums or desert regions (NRC,1991; Child, 2016). The habitat of Thryonomys swinderianus is characterized by an annual rainfall of over $750 \mathrm{~mm}$ with seven to eight months of rainfall and an annual average temperature ranging from $22^{\circ} \mathrm{C}$ to $27^{\circ} \mathrm{C}$ (Adu et. al., 2017).

Greater cane rats often live in groups of 3 to 12 individuals: 1 male and 2 to 3 females with their offsprings (Opara, 2010). Thryonomys swinderianus matures between five months and one year, age at first littering varying from 12 months to 18 months (Ewer, 1969; Asibey, 1974; Gochis, 2002). Individual animal giving birth to an average of four young in two to three litters a year with a generation length of 837.31 days and maximum longevity of 5.4 years (Onadeko and Amubode, 2002; Pacifici et. al., 2013; AnAge, 2017). Due to its reproductive success, greater cane rats are very domesticated and reared in my animal husbandries in Africa.

\subsection{METHOD}

\subsection{Study Area}

This research work was conducted in the Ogoni land. Ogoni land is a region in the Niger Delta. It is

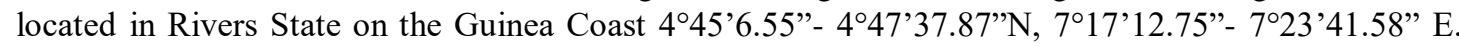
This region covers approximately 1,000 square kilometers and for purposes of administration is divided into four local government areas; Eleme, Gokana, Khana and Tai. Traditionally however, the region is divided into six kingdoms; Babbe, Gokana, Ken-khana, Nyo-khana, Eleme and Tai with a population of 850,000 (United Nations Environmental Program, UNEP, 2016; Unrepresented Nations \& Peoples Organization, UNPO, 2017). This region has an annual rainfall of $3000 \mathrm{~mm}, 27^{\circ} \mathrm{C}$ being the annual temperature. The relative humidity is between $80-100 \%$ at dawn and $70-80 \%$ during the afternoon. The vegetation is typical rainforest with thick mangroves (Offodile, 1992; Amechi, 2010).

\subsection{Feeding Ecology of Thryonomys swinderianus}

The feeding ecology of Thryonomys swinderianus in this work boarders on its feed type, feeding rate and length of feeding bout. Feed type was gotten from feed presented in captivity and from inference of crops raided on in farms. Thryonomys swinderianus is reared in the mini zoo of the Department of Science Laboratory Technology in Kenule Beeson Saro-Wiwa Polytechnic Bori. All studies of the animal's

91 | P a g e

www.iiste.org 
feeding ecology save its feeding in the wild was carried out in the mini zoo with the assistance of the zoo keeper. The feed presented to the animal in captivity was gotten from the zoo keeper after three guided interviews; the periods the animal was feed was also gotten. The feed from the wild was gotten from one hundred farmers: twenty five from each of the Local Governments Areas of Ogoni; Eleme, Tai, Gokana and Khana. A structured questionnaire was use to extract information from the farmers. Among other things, the questionnaire sought to know the size of farm, the kind of crops planted, whether or not they have seen the study animal before and on their farms, the kind of crops raided by this animal on their farm. This information, particularly the kind of crops raided by $T$. swinderianus on their farms was used to infer its feed type in the wild. Farmers and hunters do not live in isolation. Farmers by interaction with hunters know animals that raid their farms by sight of presence (foot prints \& dug up holes), pattern of feeding, feed remnants, bite patterns and decay/rot time of damage crop. Determination of feeding rate was done in a five day period. Weighed quantity of feed was presented to the animal and taken away after thirty minutes. The quantity that remained was also weighed. Feed presentation was done twice a day, morning and evening. Table 2.1 shows feed presentation to T. swinderianus.

Table 2.1 Feed Presentation: Feed Type, Periods of Presentation, Quantities Presented and Reweighed Quantities

\begin{tabular}{|l|l|l|l|l|}
\hline Day & Period & Plant Species (feed) Presented & $\begin{array}{l}\text { Quantity of } \\
\text { Feed Presented }\end{array}$ & $\begin{array}{l}\text { Quantity Feed of } \\
\text { Left }\end{array}$ \\
\hline Day 1 & Morning & Ipomea batatas (Potato) & $1000 \mathrm{~g}$ & $872 \mathrm{~g}$ \\
\hline Day 1 & Evening & Carica papaya(Pawpaw) & $300 \mathrm{~g}$ & $211 \mathrm{~g}$ \\
\hline Day 2 & Morning & Manihot esculenta (Cassava) & $300 \mathrm{~g}$ & $194 \mathrm{~g}$ \\
\hline Day 2 & Evening & Musa acuminata (Banana) & $300 \mathrm{~g}$ & $209 \mathrm{~g}$ \\
\hline Day 3 & Morning & Colocasia esculenta (Cocoyam) & $300 \mathrm{~g}$ & $188 \mathrm{~g}$ \\
\hline Day 3 & Evening & Bread (unspoilt) & $300 \mathrm{~g}$ & $196 \mathrm{~g}$ \\
\hline Day 4 & Morning & Dioscorea batatas (Three leaf yam) & $300 \mathrm{~g}$ & $204 \mathrm{~g}$ \\
\hline Day 4 & Evening & Musa paradisiacal (Plantain) & $300 \mathrm{~g}$ & $191 \mathrm{~g}$ \\
\hline Day 5 & Morning & Manihot esculenta (Cassava) & $300 \mathrm{~g}$ & $202 \mathrm{~g}$ \\
\hline Day 5 & Evening & Ipomea batatas (Potato) & $300 \mathrm{~g}$ & $198 \mathrm{~g}$ \\
\hline
\end{tabular}

The mean of the quantities eaten in thirty minutes and the standard deviation was used to arrive at the feeding rate. Mean $=(128+89+106+91+112+104+96+109+98+102) \div 10=103.5$. Standard deviation $=$ 11.4

Determination of length of feeding bout was also done in another five day period. Each day, 4000 grams of feed was presented to Thryonomys swinderianus and observed to see when it stops feeding. Seven minutes away from feeding was taken as the stop time. Table 2.2 shows feed presented and time relationship.

Table 2.2 Days, Feed Presented, Start and Stop Time of Feeding for T. swinderianus

\begin{tabular}{|l|l|l|l|}
\hline Day & Feed Presented & Start of Feeding Time & End of Feeding Time \\
\hline Day 1 & Ipomea batatas (Potato: sweet) & $8: 32 \mathrm{am}$ & $9: 58 \mathrm{am}$ \\
\hline Day 2 & Manihot esculenta(Cassava) & $8: 17 \mathrm{am}$ & $10: 01 \mathrm{am}$ \\
\hline Day 3 & Colocasia esculenta (Cocoyam) & $8: 11 \mathrm{am}$ & $9: 41 \mathrm{am}$ \\
\hline Day 4 & Manihot esculenta & $8: 21 \mathrm{am}$ & $10: 04 \mathrm{am}$ \\
\hline Day 5 & Ipomea batatas & $8: 10 \mathrm{am}$ & $9: 41 \mathrm{am}$ \\
\hline
\end{tabular}


The length of feeding bout was gotten by subtracting the time the animal stopped feeding from the time it started feeding which gives the length of feeding time. The mean of the length of feeding time and the standard deviation was used to arrive at the length of feeding bout of the animal. Mean = $(38+33+31+59+54) \div 5=43$. Standard deviation $=12.7$

\subsection{Population Ecology of Thryonomys swinderianus}

Annual hunt data was used to estimate the population of Thryonomys swinderianus. The annum for this research was July, 2017 to June, 2018. Hunt data was gotten from Eleme Hunters Association that uses gun to hunt for the animal at night; John Pialu, a hunter from Tai that uses gun to hunt for this animal at night; Gbinle Kalaap, a hunter from Gokana that uses gun and traps to hunt for this animal at night and Kenule Adokor Associate of Khana that uses machete and dogs, hunting this animal during daytime. After initial familiarization with the hunters and hunting association/associate, monthly hunt data was gotten from these hunters by visit. Tables 2.3 to 2.6 present the hunt data from the four Local Government Areas.

Table 2.3 Gokana Harvest Data.

\begin{tabular}{|l|l|l|l|}
\hline Month & $\begin{array}{l}\text { Thryonomys swinderianus } \\
\text { (Catch) }\end{array}$ & Month & $\begin{array}{l}\text { Thryonomys swinderianus } \\
\text { (Catch) }\end{array}$ \\
\hline July & 14 & January & 39 \\
\hline August & 38 & February & 44 \\
\hline September & 12 & March & 41 \\
\hline October & 43 & April & 27 \\
\hline November & 51 & May & 17 \\
\hline December & 36 & June & 26 \\
\hline & Total & Catch & $\mathbf{3 8 8}$ \\
\hline
\end{tabular}

Table 2.4 Khana Harvest Data.

\begin{tabular}{|l|l|l|l|}
\hline Month & $\begin{array}{l}\text { Thryonomys swinderianus } \\
\text { (Catch) }\end{array}$ & Month & $\begin{array}{l}\text { Thryonomys swinderianus } \\
\text { (Catch) }\end{array}$ \\
\hline July & 21 & January & 61 \\
\hline August & 66 & February & 60 \\
\hline September & 54 & March & 76 \\
\hline October & 81 & April & 58 \\
\hline November & 68 & May & 30 \\
\hline December & 46 & June & 51 \\
\hline & Total & Catch & $\mathbf{6 7 2}$ \\
\hline
\end{tabular}

Table 2.5 Eleme Harvest Data.

\begin{tabular}{|l|l|l|l|}
\hline Month & $\begin{array}{l}\text { Thryonomys swinderianus } \\
\text { (Catch) }\end{array}$ & Month & Thryonomys swinderianus (Catch) \\
\hline July & 35 & January & 98 \\
\hline August & 133 & February & 126 \\
\hline September & 142 & March & 161 \\
\hline October & 81 & April & 78 \\
\hline November & 130 & May & 53 \\
\hline December & 71 & June & 76 \\
\hline & Total & Catch & $\mathbf{1 1 8 4}$ \\
\hline
\end{tabular}


Table 2.6 Tai Harvest Data.

\begin{tabular}{|l|l|l|l|}
\hline Month & $\begin{array}{l}\text { Thryonomys swinderianus } \\
\text { (Catch) }\end{array}$ & Month & $\begin{array}{l}\text { Thryonomys swinderianus } \\
\text { (Catch) }\end{array}$ \\
\hline July & 24 & January & 30 \\
\hline August & 33 & February & 32 \\
\hline September & 22 & March & 41 \\
\hline October & 40 & April & 23 \\
\hline November & 31 & May & 21 \\
\hline December & 18 & June & 16 \\
\hline & Total & Catch & $\mathbf{3 3 6}$ \\
\hline
\end{tabular}

The total catch of Thryonomys swinderianus for the annum (July, 2017 - June, 2018) was $1184+336+$ $672+388=\mathbf{2 5 8 0}$.

The population of animals with respect to annual hunting statistics will always have this relationship; Abundance after harvest equals pre harvest abundance discounted by all mortalities plus all birth. If harvest and natural mortality is not differentiated, the relationship can be represented thus:

$\mathrm{N}_{\mathrm{t}+1}=\mathrm{N}_{\mathrm{t}}+\mathrm{B}-\mathrm{H}_{\mathrm{t}} \quad$ (equation 1)

Where $\mathbf{N}_{\mathbf{t}+1}$ : Abundance in year $\mathrm{t}+1 ; \mathbf{N}_{\mathbf{t}}$ Abundance in year $\mathrm{t}$ (pre harvest abundance). $\mathbf{B}$ : All births in year $\mathrm{t} ; \mathrm{H}_{\mathrm{t}}$ : Number of animals harvested in year $\mathrm{t}$;

$\mathrm{N}_{\mathrm{t}+1}=\left(\mathrm{N}_{\mathrm{t}}-\mathrm{H}\right) \times(\mathrm{r}+1) \quad$ (Agetsuma, 2018) (equation 2)

Where $\mathbf{r}$ : intrinsic rate of natural increase. Equation 2 also expresses the relationship of equation 1. Equation 2 when rearranged becomes

$\mathbf{N}_{\mathbf{t}}=\left\{\mathrm{N}_{\mathrm{t}+1} \div(\mathrm{r}+1)\right\}+\mathrm{H}_{\mathrm{t}} \quad$ (equation 3)

$\mathbf{N}_{\mathbf{t}}$ : Pre harvest abundance.; $\mathbf{N}_{\mathbf{t}+\mathbf{1}}$ : Abundance in year $\mathrm{t}+1$ (year after $\mathbf{N}_{\mathbf{t}}$ ); $\mathrm{H}_{\mathrm{t}}$ : Number of animals harvested in year $t ; \mathbf{r}$ : intrinsic rate of natural increase. (Equation 2 and equation 3 are from equation $1 \&$ equation 2 of Agetsuma, 2018).

Accordingly to Rinehart 2015, the population abundance of the year after harvest is represented thus:

$\mathrm{N}_{\mathrm{t}+1}=\left(\mathrm{P}_{\mathrm{t}} \times \mathrm{S}_{\mathrm{t}}\right) \quad$ (equation 4$)$

Where: $\mathbf{P}_{\mathbf{t}}=$ Post harvest abundance; $\mathbf{S}_{\mathbf{t}}$ : survival rate.

Equation 2 and equation 4 equals $\mathrm{N}_{\mathrm{t}+1}$

$\mathrm{P}_{\mathrm{t}} \times \mathrm{S}_{\mathrm{t}}=\left(\mathrm{N}_{\mathrm{t}}-\mathrm{H}_{\mathrm{t}}\right) \times(\mathrm{r}+1)$

Since harvest and natural mortality is not differentiated, post harvest abundance is pre harvest

abundance the next year before harvest commence that is $\mathrm{P}_{\mathrm{t}}=\mathrm{N}_{\mathrm{t}+1}$ (before harvest commence). With the knowledge that $\mathrm{P}_{\mathrm{t}}=\mathrm{N}_{\mathrm{t}+1}, \mathrm{~N}_{\mathrm{t}}$ on the right when assumed to be zero, the above relationship is rearranged to $\mathrm{P}_{\mathrm{t}}=\mathrm{H}_{\mathrm{t}}(\mathrm{r}+1) \div \mathrm{S}_{\mathrm{t}}$ (equation 5).

Survival rate $=1$ - mortality rate (Ueno et. al., 2010); (equation 6)

Average mortality rate $=1 \div$ Average lifespan (McCoy and Gillooly, 2008); (equation 7). The average lifespan of $T$. swinderianus is 4 years (Gochis, 2002; Opara, 2010).

Using equation 7 ,

Mortality rate of $T$. swinderianus $=1 \div 4=\mathbf{0 . 2 5}$

Using equation 6 ,

Survival rate of $T$. swinderianus $=1-0.25=\mathbf{0 . 7 5}$

Intrinsic rate of natural increase of T. swinderianus is $\mathbf{0 . 6 8}$ (Davies and Brown, 2008).

The annum of this research is July 2017 to June 2018; the abundance after harvest is abundance from July 2018 while pre harvest abundance is June 2017 to anytime down.

Population Estimation for T. swinderianus According to equation 5 ,

$\mathrm{P}_{\mathrm{t}}=\mathrm{H}_{\mathrm{t}}(\mathrm{r}+1) \div \mathrm{S}_{\mathrm{t}}=2580(1 \times 0.68) \div 0.75=\mathbf{5 7 7 9}$ According to equation 3 , 
$\mathbf{N}_{\mathbf{t}}=\left\{\mathrm{N}_{\mathrm{t}+1} \div(\mathrm{r}+1)\right\}+\mathrm{H}_{\mathrm{t}}=(5779 \div 1.68)+2580=\mathbf{6 0 2 0}$

\subsection{RESULT AND DISCUSSION}

\subsection{Result}

Feed type of Thryonomys swinderianus was gotten from feed presented in captivity and inference from crops raided on in farms.

Feed type of Thryonomys swinderianus is presented in table 3.1

Table 3.1 Feed Type of Thryonomys swinderianus

\begin{tabular}{|l|l|l|}
\hline Plant (Botanical Name) & Plant (Common Name) & Part Eaten \\
\hline Pennisetum purperum & Elephant grass & Entire grass \\
\hline Musa paradisiaca & Plantain & Fingers \\
\hline Dacryodes edulis & African native pear & Fruit \\
\hline Saccharum officinarium & Cane sugar & Stalk \\
\hline Carica papaya & Paw-paw & Fruit \\
\hline Ipomea batatas & Potato & Leaves \& tuber \\
\hline Manihot esculenta $*$ & Cassava & Stem \& tuber \\
\hline Musa acuminata & Banana & Fingers \\
\hline Psidium guajava & Guava & Fruit \\
\hline Zea mays & Maize & Cob \\
\hline Dioscorea rotundata & Yam & Tuber \\
\hline Cococasia esculenta $*$ & Cocoyam & Tuber \\
\hline Citrillus lanatus & Watermelon & Fruit \\
\hline Dioscorea batatas $*$ & Three leaf yam & Tuber \\
\hline Annona muricata & Sour sop & Fruit \\
\hline Cucumeropsi mannii $*$ & Melon & Fruit \\
\hline Telfaria occidentalis $*$ & Pumpkin & Leaves \\
\hline & Bread (unspoilt)** & Bread (unspoilt) \\
\hline & Fowl feed (finishers) $* *$ & Fowl feed (finishers) \\
\hline
\end{tabular}

Note: * Plants raided on in farms and presented in captivity; ** non plant feed.

The feeding rate of Thryonomys swinderianus was found to be $103.5+/-11.4$ grams per 30 minutes and the length of feeding bout for Thryonomys swinderianus was found to be $97+/-6$ minutes.

The population of Thryonomys swinderianus before harvest commenced in July 2017 was six thousand and twenty (6020) and the population before harvest commenced in July 2018 was five thousand seven hundred and seventy nine (5779).

\subsection{DISCUSSION}

Thryonomys swinderianus is present in the Ogoni lands; Ogoni land being part of Africa. Like Opara 2010 and Gochis 2002 opined, it is found anywhere dense grasses occur particularly in wet places as most hunters have reported. Agricultural crops do affect its distribution and greatly expand its habitat as also noted by NRC, 1991; Opara, 2010 and Child, 2016. The population of Thryonomys swinderianus before harvest commenced in July was found to be six thousand and twenty (6020) and five thousand seven hundred and seventy nine (5779) before harvest commenced in July 2018.

Thryonomys swinderianus is a herbivore; this is in concurrence with the findings of Fritzinger, 1995; Opara, 2010; Adeniye, 2014 and Agriculture Nigeria, 2014. In captivity like Opara, 2010 noted T. swinderianus adapts readily to its environment and feeds on different types of feed presented to it. It thus feed on both plant and non plant feed. It is fed twice in captivity as noted by Schrage and Yewande, 1999; Adu et. al., 2017, eating $103.5+/-11.4$ grams of feed per 30 minutes and spending $97+/-6$ minutes to eat to full. 
In the wild, Thryonomys swinderianus feeds on cultivated crops like cassava, maize, sugar cane which is in accord with the findings of Agriculture Nigeria, 2014 and Adeniye, 2014. As noted by Ntiamoa-Baidu 1997, Thryonomys swinderianus is selective in nature. Its selective nature is expressed in the kind of feed it goes for and the parts it eats. As reported by farmers and documented in this research, Thryonomys swinderianus does not raid all planted crops in farms. The findings of this work showed that $T$.

Swinderianus feeds on cassava, cocoyam, maize, melon, three leaf yam, pumpkin and sugar cane in the wild in Ogoni land. Its feeding activities on crops causes serious economic damage and set up conflict between itself and humans.

\subsection{CONCLUSION}

Thryonomys swinderianus is present in the Ogoni lands. Its population before harvest commenced in July 2017 was six thousand and twenty. It is a herbivore feeding on plant species like elephant grass, cane sugar, pawpaw, banana, guava, African native pear, cassava (stem \& tuber), plantain, maize, yam, cocoyam, potato, watermelon, three leaf yam, soursop, melon, pumpkin and non plant feed like fowl feed (finishers) and bread. The volume of feed $T$. swinderianus consume within 30 minutes is $103.5+/-11.4$ grams, feeds twice a day in captivity spending $97+/-6$ minutes to eat to full. Its feeding activities on cultivated crops causes sever economic damage to farmers and set a conflict between itself and humans. The Ogoni lands span one thousand square kilometers and is not clear if the present rate of harvest given the abundance is sustainable, further investigation is thus required.

\section{References}

Adeniyi, S (2014). Grasscutter Farming Tips for Beginners. All Students Forum. Accessed November 12, 2017 at www.allstudentsforum.com/index.php?topic $=36450$

Adu, E., Alhassan, W. S and Nelson F. S. (1999). Smallholder Farming of the Greater Cane Rat, Thryonomys swinderianus in Southern Ghana: A Baseline Survey if Management Practices. Tropical Animal Health and Production. 35: 425-431

Adu, E. K., Asafu-Adjaye, A ., Hagan, B. A and Nyameasem J. K. (2017). The Grasscutter: An Untapped Resource of Africa's Grassland. Livestock Research Institute for Rural Development 29(3) 2017.

Agetsuma, N. (2018) A Simple Method for Calculating Minimum Estimates of Previous Population Sizes of Wildlife from Hunting Records. PLoS ONE 13(6): e0198794. doi:10.1371/journal.pone.0198794

Agriculture Nigeria, (2014). Grasscutter. Accessed October 19, 2106 at www.agriculturenigeria.com/farming-production/livestock/grasscutter

Amechi, C. (2010). Environmental Studies: Ogoni Land. Report Submitted to the Environmental Affairs Department, Shell Development Company of Nigeria Ltd.

AnAge: Animal Aging and Longevity Database (2018). Thryonomys swinderianus Accessed

August 14, 2018 at

.http://genomics.senescence.info/species/entry.php?species=Atherurus_africanus.

Asibey, E.O.A., (1974). Wildlife as a source of protein in Africa South of the Sahara. Biological Conservation, 6: 32-39.

Child, M.F. (2016). Thryonomys swinderianus (errata version published in 2017). The IUCN Red List of Threatened Species 2016: e.T21847A115163896. Downloaded on 14 August 2018. 
Davies, G and Brown, D (2008). Bushmeat and Livelihood: Wildlife Management and Poverty Reduction. John Wiley \& Sons. Pg 291.

Ewer, R.F., 1969. Form and function in the grasscutter Thryonomys swinderianus Temminck (Rodentia, Thryonomyidae). Ghana Journal of Science 9: 131-149.

Fritzinger, L. (1995). Cane Rats. Walkers Mammals of the World. John Hopkins University Press. Pg 1650-1651.

Gochis, E. (2002). Thryonomys swinderianus (On-line), Animal Diversity Web. Accessed March 4, 2017 at http://animaldiversity.org

McCoy, M. W and Gillooly, J. F. (2008). Predicting Natural Mortality Rate of Plants and Animals. Ecology Letters (2008) 11: 710-716

National Research Council. (1991). Microlivestock: Little Known Small Animals with a Promising Economic Future. Washington DC: The National Academic Press pp: 147-155.

Ntiamoa-Baidu, Y. (1997). Wildlife and Food Security in Africa. Food and Agricultural Organization Guide 33. Pg 44.

Offodile, L. (1992). Soils of Niger Delta. Ambio 12:27-38.

Onadeko, S.A. and F.O. Amubode, (2002). Reproductive Indices And Performance Of Captive Reared Grasscutters (Thryonomys swinderianus, Temminck). Nigerian Journal of Animal Production, 29: 142-149

Pacifici M, Santini L, Di Marco M, Baisero D, Francucci L, Grottolo Marasini G, Visconti P, Rondinini C (2013) Database on generation length of mammals. 5427 data records. Online at http://doi.org/10.5061/dryad.gd0m3, doi: 10.3897/natureconservation.5.5734

Ramalingam, S. T. (2012). Modern Biology. African First Publisher Ltd. Pg 88-91;117-120.

Raven, P. H and Johnson, G. B. (1998). Understanding Biology 3rd edition. McGraw-Hill. Pg $382284 ; 399-404 ; 418$.

Rinehart, K. (2015). Analytical and Decision Tools for Wildlife Population and Habitat Management. Graduate College Dissertation and Thesis. Pg 393.

Schrage, R and Yewandan, L. T (1999). Raising Grasscutter. Deutsche 29 (3) 1999.

Stuart, L. P and Robert, L. S (2012). Ecology. Encyclopedia Britannica. Accessed October 12, 2016 at www.britannica.com/science/ecology

Ueno, M., Solberg, E. J., Iijima, H., Rolandsen, C. M and Gangsei, L. E. (2014) Performance Of Hunting Statistics As Spatiotemporal Density Indices Of Moose (Alces Alces) In Norway Ecosphere Volume 5, Issue 2.

United Nations Environmental Program (2016). About Ogoni Land. Accessed October 12, 2107 at www.unep.org/disasterandconficts/where-we-work/Nigeria/what-we-do/about-ogoniland

Unrepresented Nation \& Peoples Organization (2017). Ogoni Land. Accessed September 11, 2017 at unpo.org/member/7901 